\title{
THE LEADERSHIP MANAGEMENT OF SCHOOL PRINCIPALS IN IMPROVING SPIRITUAL INTELLIGENCE OF STUDENTS AT SMK YP-PGRI I MAKASSAR
}

\section{Hermansyah, Muljono Damopolii, Sitti Syamsudduha}

Islamic Education Management Postgraduate Program

Alauddin State Islamic University Makassar

Email: hermansyah.ppsmpiuinam@gmail.com, muljono.damopolii@uin-alauddin.ac.id, st.syamsudduha@uin-alauddin.ac.id

\begin{abstract}
This study aims to explain the description of the principal's leadership management in improving the spiritual intelligence of students at SMK YP-PGRI I Makassar and to explain the impact of the principal's leadership management in improving the spiritual intelligence of students at SMK YPPGRI I Makassar. The type of research used in this research is qualitative. The results showed that the principal was able to manage all school resources, including Educators, Education Personnel, Students, infrastructure, finance, administration, planning of learning programs, programs of religious activities (spiritual activities), and others. other. Planning of school learning programs through structured scheduling by the Deputy Head of Curriculum with the involvement of the Principal and Educators in the preparation. The Principal of SMK YP-PGRI I Makassar seeks to organize educators and education staff through the division of tasks to each educator and education staff based on their potential and educational background, namely the distribution of task decrees in the hope that educators and education staff can work according to their job descriptions each.
\end{abstract}

Keywords: Principal Leadership Management, Spiritual Intelligence of Students. 


\section{A. INTRODUCTION}

Education is a conscious effort to develop one's potential. This has been stated in the Law of the Republic of Indonesia Number 20 of 2003 concerning the National Education System article 1 paragraph (1) which states that: Education is a conscious and planned effort to create a learning atmosphere and learning process so that students actively develop their potential to have religious-spiritual strength, self-control, personality, intelligence, noble character, and skills needed by themselves, society, nation, and state. ${ }^{1}$

Law of the Republic of Indonesia Number 20 of 2003 concerning the National Education System in CHAPTER II article 3 which reads: National education functions to develop capabilities and shape the character and civilization of a dignified nation in the context of educating the nation's life, aiming at developing the potential of students to become human beings who have faith and fear of God Almighty, have a noble character, are healthy, knowledgeable, capable, creative, independent, and become democratic and responsible citizens. ${ }^{2}$

The Law of the Republic of Indonesia Number 20 of 2003 in CHAPTER V on SISDIKNAS, article 12, paragraph

1 Republik Indonesia, Undang-Undang RI Nomor 20 Tahun 2003 tentang Sistem Pendidikan Nasional pasal 1 ayat (1), p. 2.

2 Republik Indonesia, Undang-Undang RI Nomor 20 Tahun 2003 tentang Sistem Pendidikan Nasional, BAB II, pasal 3, p. 3. 
(1) letter a, mandates that obtaining religious education is following the religion he adheres to and taught by educators of the same religion. ${ }^{3}$

Article 30, paragraphs (1-4) confirms that: Religious education is organized by the Government and/or community groups of religious adherents, following statutory regulations. Religious education serves to prepare students to become members of the community who understand and practice the values of their religious teachings and/or become experts in religious knowledge. Religious education can be carried out through formal, non-formal, and informal education channels. Religious education is in the form of diniyah education, pesantren, pasraman, pabhaja samanera, and other similar forms. ${ }^{4}$

James AF Stoner in T. Hani Handoko argues that Management is a process of planning (planning), organizing (organizing), directing (actuating), and controlling (controlling) the efforts of organizational members and the use of other organizational resources to achieve goals. defined organization. $^{5}$

Principals who are competent in their field of duty are school principals who have competencies as described in the

$3{ }^{3}$ Republik Indonesia, Undang-Undang RI Nomor 20 Tabun 2003 tentang SISDIKNAS, pasal 12, ayat (1) huruf a, p. 5.

${ }^{4}$ Republik Indonesia, Undang-Undang RI Nomor 20 Tabun 2003 tentang SISDIKNAS, Pasal 30, ayat (1-5), p. 10.

5 T. Hani Handoko, Manajemen, Edisi 2 (Yogyakarta: BPFEYogyakarta, 2013), p. 8. 


\section{Hermansyah}

Regulation of the Minister of National Education of the Republic of Indonesia Number 13 of 2007, concerning the standards of principals/madrasahs, namely the competence of principals including personality, managerial, entrepreneurial, supervision competencies, and social.

According to Ngermanto, spiritual intelligence is a non-material dimension that is used to "connect" with God which is not limited by heredity, environment, or other material factors. ${ }^{6}$

A person's spiritual intelligence is defined as the ability of someone who has skills, high skills to build a life using spiritual resources to solve life's problems and be virtuous. He can relate well to God, humans, nature, and oneself. ${ }^{7}$

Based on the description above, the authors are interested in researching with the title: "Leadership Management of Principals in Improving the Spiritual Intelligence of Students at SMK YP-PGRI I Makassar".

\section{B. THEORETICAL REVIEW}

1. Management

Management etymologically (language) comes from the word to manage which means managing or managing. In line with Gomes that management comes from the verb to

${ }^{6}$ Republik Indonesia, Peraturan Menteri Pendidikan Nasional RI Nomor 13 Tahun 2007, p. 3-7

7 Wahyudin Siswanto, Membentuk Kecerdasan Spiritual Anak (Jakarta: Amza, 2010), p. 11 
manage, which means to manage, organize, implement, and manage. ${ }^{8}$ This understanding indicates that management is a technique to regulate, therefore in management it is necessary to regulate the elements contained in the elements of management (man, money, methods, machines, materials, and markets), what is the purpose in regulating, why should it be regulated, who regulates it, and how to regulate it. ${ }^{9}$

Prajudi Atmosudirjo's view defines management as a process of planning, organizing, staffing, leading, controlling for optimizing the use of resources, and carrying out tasks in achieving organizational goals effectively and efficiently. ${ }^{10}$

Peter P. Schoderbek said, "Management is a process of achieving organizational goals through others". ${ }^{11}$ Management is the process of achieving goals in an organized manner through (cooperation) with other people.

George R. Terry and Leslie W. Rue in their book Principle of Management translated by G. A. Ticoalu argues that management is a process or framework that involves

8 Andang, Manajemen \& Kepemimpinan Kepala Sekolah (Yogyakarta: Arruzi Media, 2014), p. 5.

9 Faustino Cardoso Gomes, Manajemen Sumber Daya Manusia (Yogyakarta: Andi Offset, 2007), p. 1.

10 Prajudi Atmosudirjo, Administrasi dan Manajemen Umum (Jakarta: Ghalia, 2006), p. 125.

11 Peter P. Schoderbek, et. al., Management (London: Harcourt Brace Jovanovich Publishers, 2001), p. 8. 


\section{Hermansyah}

guiding or directing a group of people towards organizational goals $^{12}$.

James A. F. Stoner in T. Hani Handoko argues that Management is the process of planning, organizing, directing, and supervising the efforts of organizational members and the use of other organizational resources to achieve predetermined organizational goals. ${ }^{13}$

T. Hani Handoko stated that: Management involves achieving the stated goals (Stated Goals). The functions of planning (planning), organizing (organizing), preparation of personnel or staffing (staffing), direction and leadership (leading), and supervision (controlling). ${ }^{14}$

The management elements are as follows:
a. Human (Man).
b. Materials (Materials).
c. Machine (Machine).
d. Method (Method).
e. Money (Money). ${ }^{15}$
f. Markets (Markets). ${ }^{16}$

12 George R. Terry dan Leslie W. Rue, Dasar-dasar Managemen, Priciple of Management (Dasar-dasar Manajemen) terj. G. A. Ticoalu (Jakarta: Bumi Aksara, 2000), p. 1.

13 T. Hani Handoko, Manajemen, Edisi 2 (Yogyakarta: BPFEYogyakarta, 2013), p. 8.

14 T. Hani Handoko, Manajemen, Edisi 2, p. 10.

15 Agustini, Pengelolaan dan Unsur-unsur Manajemen (Jakarta: Citra Pustaka, 2013), p. 61.

16 Agustini, Pengelolaan dan Unsur-unsur Manajemen, p. 62. 
According to Wursanto, the functions of management are planning, organizing, directing, and controlling. ${ }^{17}$

a. Planning (Planning)

Planning can be interpreted as the whole process of thinking and determining all activities that will be carried out in the future to achieve goals. ${ }^{18}$

Planning in Islam is the most important part in achieving the goals of Islamic education as His word QS al-Hasyr/59: 18.

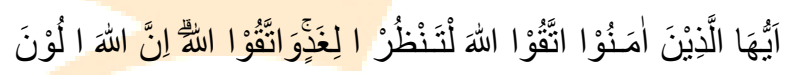

The translation:

O you who believe! fear Allah and let everyone pay attention to what he has done for tomorrow (hereafter), and fear Allah. Indeed, Allah is thorough in what you do. ${ }^{19}$

Tafsir Jalalain explains that everyone should pay attention to what has been done for tomorrow, namely to face the Day of Judgment. ${ }^{20}$

b. Organizing

${ }^{17}{ }^{17}$ I.G. Wursanto, Dasar-Dasar Manajemen Umum (Jakarta: Pustaka Dian, 2000), p. 20.

18 Ibrahim Bafadal, Manajemen Peningkatan Mutu Sekolah Dasa dari Sentralisasi Menuju Desentralisasi (Jakarta: Bumi Aksara, 2003), p. 42.

19 Departemen Agama RI, al-Qur'an dan Terjemahnya, Cet. 1, p. 548.

20 Jalaluddin Almahalli and Jalaluddin Assuyuti, Tafsir Jalalain (Semarang: Family Business, tt), p. 342. 


\section{Hermansyah}

Organizing is the whole process of grouping all tasks, responsibilities, authorities, and components in the collaborative process ${ }^{21}$.

As the word of Allah swt. in QS 'Ali 'Imrān/3: 103. Allah swt conveys about the need for such organization:

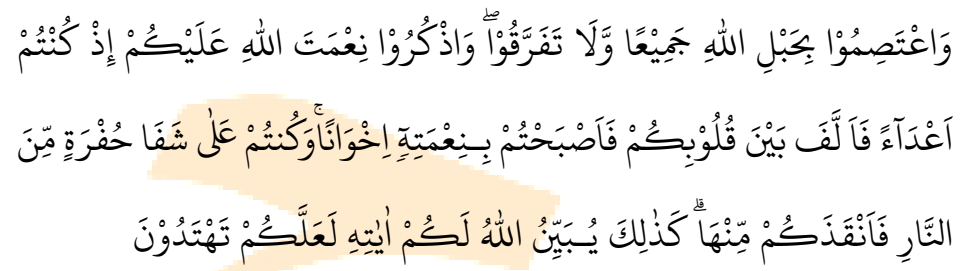

The translation:

And hold fast all of you to the rope (religion) of Allah, and do not be divided, and remember Allah's favor upon you when you were enemies, then Allah united your hearts, so that by His grace you became brothers, while (at that time) ) you are on the edge of the abyss of hell, then Allah saves you from there. Thus, Allah explains His verses to you so that you may be guided ${ }^{22}$.

Based on Jalalain's interpretation, it is explained that Allah swt. said: hold fast to the religion of Allah swt. everything and does not divide after Islam. Remember Allah's

21 Puslitbang Pendidikan Agama dan Keagamaan Badan Litbang Agama dan Diklat Keagamaan Keagamaan, Konsep Dasar Manajemen Madrasab Mandiri, 2003, p. 15.

22 Departemen Agama RI, Al-Qur'an dan Terjemahnya, Cet. 1, p. 63. 
favor on you where you were before Islam enemies then Allah swt. unite your hearts with Islam ${ }^{23}$.

c. Supervision (Controlling)

Didin and Herdi stated that in the view of Islam, supervision is carried out to straighten out what is not straight, correct what is wrong, and correct what is right ${ }^{24}$.

The verse that discusses supervision is in QS Qaf/50: 16-18.

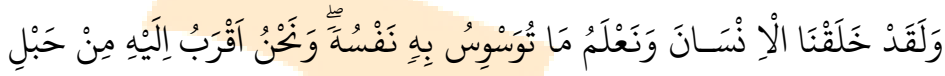

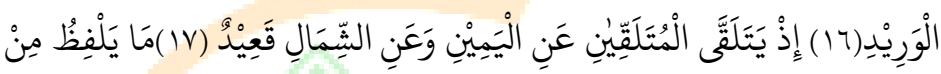

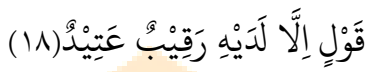

The translation:

And indeed We have created man and know what his heart whispers, and We are closer to him than his jugular vein. (Remember) when two angels recorded (his deeds), one sitting on the right and the other on the left. He did not say anything but was by his side the guardian angel who was always ready (to take notes) ${ }^{25}$.

The book of interpretation of Jalalain explains that the sentence "closer than the jugular vein" is the knowledge of

${ }^{23}$ Jalaluddin, Tafsir Jalalain, p. 249.

24 Didin Hafidudin and Hendri Tanjung, Manajemen Syariah dalam Praktike (Jakarta: Gema Insani, 2003), p. 101.

25 Departemen Agama RI, Al-Qur'an dan Terjemahnya, Cet. 1, p. 519. 


\section{Hermansyah}

Allah, meaning that Allah's knowledge knows everything that exists in the universe, including the whispers of the human heart ${ }^{26}$.

\section{Leadership}

According to Soekarto Indrafachrudi, et al. Leadership is: Means the ability and readiness possessed by a person to be able to influence, encourage, invite, guide, move in the achievement of certain goals or objectives ${ }^{27}$.

Allah SWT. emphasizes that humans are the leaders to organize and manage this earth. As explained in the QS al Baqarah/2: 30 .

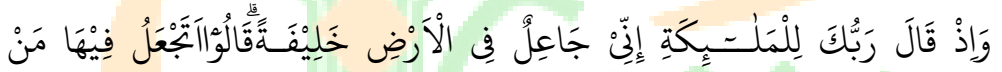

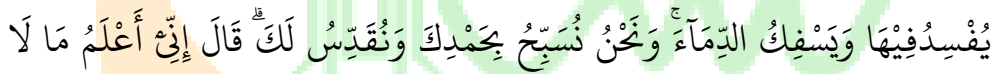

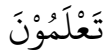

The translation:

And (remember) when your Lord said to the angels, "I want to make a caliph on earth". They said, "Are you going to make people who destroy and shed blood

${ }^{26}$ Jalaluddin, Tafsir Jalalain, p. 426.

27 Soekarto Indra Fachrudi, Pengantar Kepemimpinan Pendidikan (Surabaya: Usana Offset Printing, 2001), p. 23. 
there, while we glorify You and sanctify Your name?" He said, "Truly, I know what you do not know ${ }^{28}$.

According to Imam Munawir, the harmonious relationship between the leader and the led is very decisive, because leadership is a close relationship between a person and a group of people who come together because of common interests. ${ }^{29}$

\section{Principal}

The principal can be defined as a functional teacher who is given the task of leading the school where the teaching and learning process is held, or a place where there is an interaction between teachers who give lessons and students who receive lessons ${ }^{30}$.

The main duties of the Principal in his capacity as a school leader:

a. Leading and managing the situation,

b. Convincing others about the need for change for the better,

c. Remind the end goal of the change.

d. Help smooth the change process

28 Departemen Agama RI, Al-Qur'an dan Terjemabnya, Cet. 1, p. 6.

29 Imam Munawir, Azas-azas Kepemimpinan dalam Islam (Surabaya; Usaha Nasional; tt), p. 13.

30 Wahjosumidjo, Kepemimpinan Kepala Sekolah (Tinjauan Teoritik dan Permasalahanya) (Jakarta: PT RajaGrafindo Persada, 2008), p. 83. 
e. Connecting people with the necessary sources of funds ${ }^{31}$.

According to Aswarni Sujud, Moh. Saleh and Tatang M. Amirin in their book Daryanto "Education Administration" state that the principal functions are as follows:

a. Formulation of work objectives and school policymakers.

b. Regulating school work procedures, which regulates the division of tasks and regulates the division of tasks and regulates implementing officers, organizes activities.

c. Supervising school activities, including regulating activities, directing the implementation of activities, evaluating the implementation of activities, guiding and improving the ability of implementers ${ }^{32}$.

The main duties and functions of the Principal as an educational leader are:
a. School planning.
b. Organizing schools.
c. Move staff.
d. Supervise.

31 Hasan Basri, Kepemimpinan Kepala Sekolah (Bandung: Pustaka Setia, 2014), p. 43.

32 Daryanto, Administrasi Pendidikan (Jakarta: Rineka Cipta, 2001), p. 8 . 
e. Evaluating educational processes and outcomes ${ }^{33}$.

The Decree of the Minister of National Education (Mendiknas) Number 162 of 2003 in Doni Juni Pariansyah regarding the guidelines for assigning teachers as school principals stated that the duties of school principals are educators, managers, administrators, supervisors, leaders, entrepreneurs, and climate creators. These tasks are often abbreviated as EMASLEC ${ }^{34}$.

According to the Regulation of the Minister of National Education of the Republic of Indonesia Number 13 of 2007 article 1, it is stated that to be appointed as a Head of School/Madrasah, a person must meet the standards of the Head of the School/Madrasah that apply nationally. Article 2, confirms that the Standards of the Principal/Madrasah as referred to in paragraph 1 are listed in the attachment to this ministerial regulation ${ }^{35}$.

As for the attachment to the Regulation of the Minister of National Education of the Republic of Indonesia Number 13 of 2007 concerning Standards for Principals / Madrasas, that Principals must have competency standards:

33 Hari Sudrajat, Manajemen Peningkatan Mutu Berbasis Sekolah (Bandung: Cipta Cekas Grafika, 2004), p. 112.

34 Doni Juni Pariansyah, Manajemen Supervisi dan Kepemimpinan Kepala Sekolah (Bandug: Alfabeta, 2014), p. 53-54.

35 Republik Indonesia, Peraturan Menteri Pendidikan Nasional RI Nomor 13 Tabun 2007, tentang Standar Kepala Sekolah/Madrasah, p. 1-2 


\section{Hermansyah}

(1) personality competence, (2) managerial competence, (3) supervisory competence and (4) social competence "

4. Spiritual Intelligence ${ }^{36}$

According to Danah Zohar in his book Akhmad Muhaimin, spiritual intelligence is the highest form of intelligence that combines the two previous forms of intelligence, namely intellectual intelligence and emotional intelligence ${ }^{37}$.

Ary Ginanjar Agustian that spiritual quotient is a person's ability to be able to implement religious values as the center of belief and the basis for doing everything right and able to synergize IQ, EQ, and SQ comprehensively ${ }^{38}$.

As a simple example of the implementation of Allah's spiritual intelligence. said in QS Luqman/31:17.

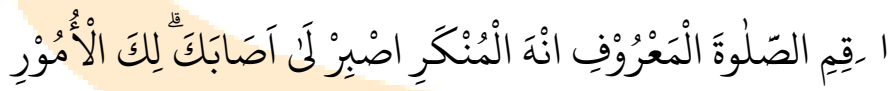

The translation:

Oh, my son! Pray and command (humans) to do what is right and prevent (them) from doing what is wrong

36 Republik Indonesia, Peraturan Menteri Pendidikean Nasional RI Nomor 13 Tabun 2007, tentang Standar Kepala Sekolab/Madrasah, p. 3-7

37 Akhmad Muhaimin Azzet, Mengembangkean Kecerdasan Spiritual Bagi Anak (Jogjakarta: Kata Hati, 2010), p. 31.

38 Ary Ginanjar Agustian, ESQ Emotional Spiritual Quotient (Jakarta: Arga, 2006), p. 47. 
and be patient with what befalls you, indeed that is an important matter ${ }^{39}$.

The steps to developing spiritual intelligence are getting used to thinking positively, giving the best, and digging wisdom in every incident ${ }^{40}$.

\section{Learners}

According to the Law of the Republic of Indonesia No. 20 of 2013 article 1 paragraph 4 concerning the National Education System, where students are members of the community who try to develop themselves through the educational process at certain paths and levels and types of education $^{41}$.

Students are subjects and objects of education who need the guidance of others (educators) to help develop their potential and guide them to maturity. Potential is a basic ability possessed by students, and will not grow or develop optimally without the guidance of educators ${ }^{42}$.

\section{RESEARCH METHODOLOGY}

39 Departemen Agama RI, Al-Qur'an dan Terjemahnya, Cet. 1, p. 412.

40 Akhmad Muhaimin Azzet, Mengembangkean Kecerdasan Spiritual Bagi Anak, p. 50.

41 Republik Indonesia, Undang-Undang RI Nomor 20 Tahun 2003 tentang Sistem Pendidikan Nasional.

42 Yasin al-Fatah, Dimensi-dimensi Pendidikan Islam (Malang: UINMalang Press, 2008), p. 100. 


\section{Hermansyah}

The type of research used in this research is qualitative, namely the type of field research which is usually called "field research". Field research (Field Research), with the type of qualitative descriptive research, is research conducted to interpret the object as it is ${ }^{43}$.

This research is a form of field research (field research) that is descriptive qualitative, using a scientific approach, namely, philosophical, sociological, psychological, and managerial. The paradigm approach is the critical paradigm and the constructivist paradigm ${ }^{44}$. The author also uses several instruments to obtain data, including observation guidelines, interview guidelines, and documentation formats. The types of data needed in this study are primary data and secondary data ${ }^{45}$. While the data collection techniques used are observation $^{46}$, interviews ${ }^{47}$, and documentation ${ }^{48}$.

The data analysis used in this research is a descriptive technique that is carried out through three activity lines, namely: (1) data reduction; (2) data presentation; and (3)

${ }^{43}$ Faisal, Sanapiah, Penelitian Kualitatif Dasar-Dasar dan Aplikasi (Malang: IKIP Malang, 2011), p. 57

44 Faisal, Sanapiah, Penelitian Kualitatif Dasar-Dasar dan Aplikasi (Malang: IKIP Malang, 2011), p. 57

${ }^{45}$ Sugiyono, Metode Penelitian Pendidikan Pendekatan Kuantitatif, Kualitatif dan R\&D, p. 137.

46 Sugiyono, Metode Penelitian Pendidikan Pendekatan Kuantitatif, Kualitatif dan R\&D, p. 145

47 Asep Saeful Muhtadi dan Agus Ahmad Safei, Metode Penelitian Dakwah, Cet I (Bandung: CV. Pustaka Setia, 2003), p. 161

48 Sulaiman Saat dan Sitti Maniah, Pengantar Metodologi Penelitian, Panduan Bagi Peneliti Pemula (Makassar: Penerbit Sibuku, 2018), p. 88. 
drawing conclusions or verification ${ }^{49}$. While the informants as resource persons are the principal, educators, and students. The validity of the data that can be accounted for is carried out by the following steps: extension of observations, increasing persistence, triangulation. ${ }^{50}$

\section{RESEARCH RESULTS AND DISCUSSION}

\section{Overview of the Principal's leadership management in Improving the Spiritual Intelligence of Students at SMK YP-PGRI I Makassar}

a. Management leadership of the Principal of SMK YPPGRI I Makassar

The principal is the head of leadership in the school. The principal must have the right concepts and tips as a school leader, to make the school he leads successfully. This goal will be achieved successfully if the concept and realization of leadership management are implemented properly.

To become a school leader, one must have good management skills in leading, especially planning, directing, and motivating people or their subordinates to achieve the right goals.

49 Matthew B. Miles dan A. Michael Huberman, Qualitative Data Analysis, Diterjemahkan oleh Tjetjep Rohendi Rohidi, Analisis Data Kualitatif., p. 16

50 Sugiyono, Metode Penelitian Pendidikan Pendekatan Kuantitatif, Kualitatif dan R\&D, p. $271-273$ 


\section{Hermansyah}

Good leadership management is a leader who can manage or manage all school resources properly. Not only that, it turns out that quality school leaders must also be able to provide good motivation to their subordinates and students in carrying out the learning process.

Islam also obliges everything to be done in a neat, correct, orderly, and orderly manner. The processes must be followed properly and should not be done carelessly. Starting from the smallest affairs such as managing household affairs to the biggest affairs such as managing the affairs of a country. All of this requires good, precise, and directed arrangements within the framework of management so that the goals to be achieved can be achieved and can be completed effectively and efficiently.

The leader in an educational institution in this case a school or madrasa is called the principal. The principal is fully responsible for the good and bad of the institution he leads. For this reason, every Principal of SMK YP-PGRI I Makassar is a private educational institution that has good enough quality to compete with other private schools in Makassar City.

b. The application of leadership management for the Principal of SMK YP-PGRI I Makassar in general in improving the spiritual intelligence of students. 
The leadership management efforts implemented by the Principal of SMK YP-PGRI I Makassar to improve the spiritual intelligence of students.

The principal has a pretty good ability in managing the school so far, as stated by the Deputy Head of Curriculum. Moreover, in managing activities to increase the spiritual intelligence of students, such as recitation activities and congregational midday prayers continuously.

The principal in managing also has authority over the facilities and infrastructure in the school environment he leads so that the learning implementation process can take place safely and peacefully. The existing facilities and infrastructure at SMK YP-PGRI I Makassar are pursued by the Foundation which is then given authority to the Principal to manage such as the procurement of existing facilities at the school.

Managing students is done through various approaches that must be pursued so that students are willingly willing to take part in various activities at school, especially in terms of educating their spirituality. The approaches referred to are individual social approaches and group social approaches in managing students.

The direct involvement of the principal can have a very positive effect on increasing the spiritual intelligence of students. 
c. Planning (planning) for the Principal of SMK YPPGRI I Makassar in increasing the spiritual intelligence of students

To carry out spiritual activities, the Principal and Educators are required to discuss and develop plans for the achievement of a systematic process of implementing activities.

Achieving the results of the activities that are sought depends on careful planning or not. Therefore, the principal must be directly involved in the preparation of careful planning to achieve effective and efficient goals.

d. Organizing the Principal of SMK YP-PGRI I Makassar in improving the spiritual intelligence of students spiritual

The Principal of SMK YP-PGRI I Makassar seeks to organize educators and education staff based on the background and potential of the educators and education. This means that a good principal is a principal who can put his position in charge of educators and education personnel to carry out their duties and responsibilities efficiently and effectively.

Efforts to prepare quality resources at SMK YPPGRI I Makassar through rigorous recruitment to obtain quality educators and education. However, in this case, the 
researcher is of the view that in addition to inadequate recruitment, special training is needed to develop quality resources.

e. Directing (actuating) the Principal of SMK YP-PGRI I Makassar in improving the spiritual intelligence of students

Management of direction (actuating) which is pursued by the Principal as a leader in improving the spiritual intelligence of students always provides guidance and motivation for students to continue to carry out routine recitation activities and congregational midday prayers at school.

The management of direction that is sought is nothing but an effort to provide guidance and motivation, especially in terms of aqidah and morals for students. Likewise, educators do to students, among others, fostering and motivating students to continue carrying out recitation activities and dzuhur prayers in the congregation.

The involvement of the Principal in terms of directing Educators to continue to guide students in addition to the guidance carried out by the Principal.

f. Supervision (controlling) of the Principal of SMK YPPGRI I Makassar in improving the spiritual intelligence of students 


\section{Hermansyah}

All forms of activities and management of school activities require ongoing supervision by school leaders.

Management supervision (controlling) is pursued by the principal in improving the spiritual intelligence of students so that its implementation can be pursued seriously by educators and students.

Supervision in implementing school programs must be based on appropriate implementation standards so that the achievement of goals can be carried out effectively and efficiently.

Routine recitations and congregational prayers that are carried out require monitoring, which supervision is based on the initial planning reference so that the implementation of activities can take place effectively and efficiently as a whole.

g. Spiritual intelligence is the scope of worshiping Allah swt. and apply the moral values of mah easy

The implementation of spiritual activities carried out by school principals and educators is not just aborting obligations in the program. But trying to fix the aqidah and morals of students so that they become quality humans or generations in the future. Spiritual intelligence is not only understood in terms of theory but also must be applied in life continuously. 
The researcher concludes that how important it is for students as Islamic humans to understand the sciences of aqidah and morals and apply them in life without any sense of burden within themselves to be carried out continuously both inside and outside school.

\section{The impact of the principal's leadership management in improving the spiritual intelligence of students at SMK YP-PGRI I Makassar}

A successful leader can manage the organization, can influence others, and show the right way and behavior that must be done together (doing cooperation), and even a leader greatly influences the spirit of group work.

The leadership management of the Principal of SMK YPPGRI I Makassar can manage schools effectively and efficiently so that they can produce quality students, especially in terms of efforts to improve the spiritual intelligence of the students themselves.

The leadership management pursued by the principal in improving the spiritual intelligence of students gives positive results as a provision in the future. Especially those related to simple morals which they may not get outside of school. So the researchers concluded that the implementation of these activities, in this case, routine recitations and congregational prayers, would work well if they were carried out by good leadership management of the Principal. 


\section{E. CLOSING}

Based on the research that the author conducted at SMK YP-PGRI I Makassar regarding the management of the principal's leadership in improving the spiritual intelligence of students, it can be concluded that:

1. Overview of the principal's leadership management in improving the spiritual intelligence of students at SMK YPPGRI I Makassar

a. The ability of the Principal as a leader in understanding leadership management as a whole can be categorized quite well based on the results of interviews conducted by researchers with informants who are seen from the impact of the Principal's leadership management, thus facilitating the process of school management and learning activities in schools. Because, that can be seen in the achievement of an effective and efficient learning process, especially in the effort to increase the spiritual intelligence of students at SMK YP-PGRI I Makassar.

b. The Principal can manage all school resources, including Educators, Education Personnel, Students, infrastructure, finance, administration, planning of learning programs, programs of religious activities (spiritual activities), and others. So that to improve the quality of students according to the demands of education in general, especially efforts to improve the spiritual intelligence of students. 
c. Planning of school learning programs through structured scheduling by the Deputy Head of Curriculum with the involvement of the Principal and Educators in the preparation. This includes planning spiritual activity programs (routine recitations and congregational dzuhur prayers) which are integrated into the subject group schedule.

d. The Principal of SMK YP-PGRI I Makassar seeks to organize educators and education staff through the division of tasks to each educator and education staff based on their potential and educational background, namely the distribution of task decrees in the hope that educators and education staff can work according to their job description each.

e. Guidance efforts are carried out by the Principal through his leadership management by providing training or coaching for Educators and Education Personnel to carry out their duties effectively and efficiently. In particular, understanding spiritual learning (routine recitations and dzuhur prayers in congregation) by motivating students so that the understanding of these students can be implemented in their lives continuously.

f. The principal as a school leader seeks to supervise the continuity of learning activities in schools, especially spiritual activities (routine recitations and congregational midday prayers) so that activities can take place in an orderly manner as previously planned 


\section{Hermansyah}

and supervision also needs to be sought so that learning can take place effectively and efficiently.

g. Activities to increase the spiritual intelligence of students are pursued by the principal through his leadership management so that students always worship Allah swt. through the cultivation of aqidah and morals. One of them is mah easy morals (behave well, be honest, humble, polite, do justice, be ashamed of bad deeds, be patient and behave well).

2. The impact of the principal's leadership management in improving the spiritual intelligence of students at SMK YPPGRI I Makassar

a. Principals can manage schools effectively and efficiently based on careful initial planning, especially managing spiritual activities (routine recitations and congregational midday prayers) properly and optimally to improve the spiritual intelligence of students.

b. The principal can make SMK YP-PGRI I Makassar able to compete with other schools. Because, through good leadership management, especially management to improve the spiritual intelligence of students, among others, through routine recitation activities and congregational midday prayers. 


\section{REFERENCES}

Abdullah, Mas Udik. Meledakkan IESQ Dengan Langkah Takwa \& Tawakal. Jakarta: Zikrul Hakim, 2005.

Agustian, Ary Ginanjar. ESQ Rahasia Sukses Membangun Kecerdasan Emosi dan Spiritual. Jakarta: Arga Wijaya Persada, 2001.

Agustian, Ary Ginanjar. ESQ Emotional Spiritual Quotient. Jakarta: Arga, 2006.

Agustini. Pengelolaan dan Unsur-unsur Manajemen. Jakarta: Citra Pustaka, 2013.

Al-Fatah, Yasin. Dimensi-dimensi Pendidikan Islam. Malang: UIN-Malang Press, 2008.

Almahalli, Jalaluddin dan Jalaluddin Assuyuti. Tafsir Jalalain. Semarang: Usaha Keluarga, tt.

Andang. Manajemen \& Kepemimpinan Kepala Sekolah. Yogyakarta: Arruzi Media, 2014.

Arikunto, Suharsimi. Prosedur Penelitian Suatu Pendekatan Prkatis. Jakarta: Rineka Cipta, 2006.

Atmosudirjo, Prajudi. Administrasi dan Manajemen Umum. Jakarta: Ghalia, 2006.

Azzet, Akhmad Muhaimin. Mengembangkan Kecerdasan Spiritual Bagi Anak. Jogjakarta: Kata Hati, 2010. 


\section{Hermansyah}

Bafadal, Ibrahim. Manajemen Peningkatan Mutu Sekolah Dasa dari Sentralisasi Menuju Desentralisasi. Jakarta: Bumi Aksara, 2003.

Syamsul Bakhri (47 Tahun). Kepala Sekolah SMK YP-PGRI I Makassar, Sulawesi Selatan, W awancara. Makassar, (25 Maret 2021).

Basri, Hasan. Kepemimpinan Kepala Sekolah. Bandung: Pustaka Setia, 2014.

Bogdan, C. Robert dan Sari Knopp Biklen. Qualitative Research in Education, an Introduction to Theory and Methods, Edisi ke III; Boston: Allyn and Bacon, 1998.

Daryanto. Administrasi Pendidikan. Jakarta: Rineka Cipta, 2001.

Daud, Selvianti. Kepemimpinan Spiritual Kepala Sekolah dalam Penguatan Karakter Siswa di Sekolah Menengah atas Terpadu Wira Bhakti Gorontalo, Tesis. Gorontalo: Jurusan Manajemen Pendidikan, Universitas Negeri Gorontalo, 2018.

Departemen Agama RI. Al-Qur'an dan Terjemahnya, Cet. 1 Jakarta: PT Suara Agung, 2018.

Fahmi, Irham. Manajemen Kepemimpinan, Teori \& Aplikasi. Bandung: Alfabeta, 2017.

Fatah, Nanang. Konsep Manajemen Berbasis Sekolah (MBS) \& Dewan Sekolah. Bandung: Bani Quraisy, 2004. 
Gomes, Faustino Cardoso. Manajemen Sumber Daya Manusia. Yogyakarta: Andi Offset, 2007.

H. Nata, Abuddin. Metodologi Studi Islam, Edisi Revisi. Jakarta: PT Raja Grafindo Persada, 2007.

Hafidudin, Didin dan Hendri Tanjung. Manajemen Syariah dalam Praktik. Jakarta: Gema Insani, 2003.

Handanignrat. Pengantar Suatu Ilmu Administrasi dan Manajemen. Jakarta: Gunung Agung, 2002.

Handoko, T. Hani. Manajemen, Edisi 2 .Yogyakarta: BPFEYogyakarta, 2013.

Idris, M. Isa. Kepemimpinan Kepala Madrasah dalam Meningkatkan Mutu Pendidikan di Min 3 Waykanan, Tesis. Lampung: Institut Agama Islam Negeri Raden Intan, 2018.

Fachrudi, Soekarto Indra. Pengantar Kepemimpinan Pendidikan. Surabaya: Usana Ofset Printing, 2001.

Kayo, Khatib Pahlawan. Kepemimpinan Islam dan Dakwah. Cet. I; Jakarta: Amzah, 2005.

Learning together", Just another WordPress.com site. https://yogipoltek. wordpress.com/2013/05/23/kerangka-konseptual/ (23 Mei 2013).

Makmun, Abin Syamsuddin. Psikologi Pendidikan. Bandung: PT Rosda Karya Remaja, 2003. 
MasMbull. "Undang-Undang Dasar 1945 tentang Hak dan kewajiban warga negara Pasal 31". http://ukiesociety.blogspot.com/2011/02/hak-dan-kewajibanwarga-negara-dalam.html (8 Februari 2011).

Miles, B. Matthew. dan A. Michael Huberman. Qualitative Data Analysis, Diterjemahkan oleh Tjetjep Rohendi Rohidi, Analisis Data Kualitatif. Jakarta: UI Press, 2000.

Moleong, J. Lexi. Metodologi Penelitian Kualitatif. Bandung: Remaja Rosdakarya, 2007.

Muhajir, Noeng. Metodologi Penelitian Kualitatif. Yogyakarta: Rake Sarasin, 2001.

Muhtadi, Asep Saeful dan Agus Ahmad Safei. Metode Penelitian Dakwah, Cet I. Bandung: CV Pustaka Setia, 2003.

Muklasin, Ali. Pengembangan Kecerdasan Spiritual dalam Meningkatkan Sumberdaya Guru (Studi Multi Kasus di SDI Al-Fath Pare dan MIN Doko Ngasem Kabupaten Kediri), Tesis. Malang: Sekolah Pasca Sarjana Universitas Islam Negeri Maulana Malik Ibrahim Malang, 2013.

Munawir, Imam. Azas-ąas Kepemimpinan dalam Islam. Surabaya; Usaha Nasional; tt.

Novlan, Yosi dan N. Faqih Syarif H. QLA-T. Surabaya: PT Java Pustaka Media Utama, 2008. 
Pariansyah, Doni Juni dan Rismi Somad. Manajemen supervisi dan kepemimpinan Kepala Sekolah. Bandug: Alfabeta, 2014.

Poerwadarminto, W.J.S. Kamus Besar Bahasa Indonesia. Cet. III; Jakarta: Balai Pustaka, 2005.

Puslitbang Pendidikan Agama dan Keagamaan Badan Litbang Agama dan Diklat Keagamaan Keagamaan. Manajemen Madrasah Mandir. Jakarta: Puslitbang Pendidikan Agama dan Keagamaan, 2003.

Prihatin, Eka. Manajemen Peserta Didik. Bandung: Alfabeta, 2011.

Republik Indonesia. Undang-Undang RI Nomor 20 Tahun 2003 tentang Sistem Pendidikan Nasional, BAB II, pasal 3.

Republik Indonesia. Undang-Undang RI Nomor 20 Tahun 2003 tentang SISDIKNAS. pasal 12 ayat (1) huruf a.

Republik Indonesia. Undang-Undang RI Nomor 20 Tahun 2003 tentang Sistem Pendidikan Nasional pasal 1 ayat (1).

Republik Indonesia, Undang-Undang RI Nomor 20 Tahun 2003 tentang SISDIKNAS, Pasal 30, ayat (1-5).

Republik Indonesia, Peraturan Menteri Pendidikan Nasional RI Nomor 13 Tahun 2007. 


\section{Hermansyah}

Ritzer, George. Sosiologi Ilmu Pengetahuan Berparadigma Ganda, Terjemahan Alimandan. Jakarta: PT. RajaGrafindo Perkasa, 2009.

Saat, Sulaiman dan Sitti Maniah. Pengantar Metodologi Penelitian, Panduan Bagi Peneliti Pemula. Makassar: PenerbiSibuku, 2018.

Sagala, Syaiful. Kemampuan Profesional Guru dan Tenaga Kependidikan. Bandung: Alfabeta, 2009.

Sanapiah, Faisal. Penelitian Kualitatif Dasar-Dasar dan Aplikasi. Malang: IKIP Malang, 2011.

Sarifuddin. Kepemimpinan Kepala Sekolah Berbasis Kecerdasan Emosional di SMAN 1 Soppeng Riaja Kabupaten Barru Propinsi Sulawesi Selatan, Tesis. (Makassar: Universitas Muslim Indonesia (UMI) Sulawesi Selatan).

Satiadarma, Monty P. dan Fidelis E. Waruwu. Mendidik Kecerdasan. Jakarta: Media Grafika, 2003.

Schoderbek, Peter P., et. al. Management. London: Harcourt Brace Jovanovich Publishers, 2001.

Selvianti Daud. Kepemimpinan Spiritual Kepala Sekolah dalam Penguatan Karakter Siswa di Sekolah Menengah atas Terpadu Wira Bhakti Gorontalo, Tesis. Gorontalo: Jurusan Manajemen Pendidikan, Universitas Negeri, 2018. 
Siahaan, Amiruddin dkk. Manajemen Pendidikan Berbasis Sekolah. Ciputat: Quantum Teaching, 2006.

Siahaan, Amiruddin dan Wahyuli Lius Zein. Administrasi Satuan Pendidikan Pendekatan dalam Pengelolaan Pendidikan Untuk Meningkatkan Efektifitas Pencapaian Tujuan Pada Satuan Pendidikan. Medan: Perdana Publishing, 2012.

Siswanto, Wahyudi. Membentuk Kecerdasan Spiritual Anak. Jakarta: Amzah, 2012.

Soetopo, Hendiyat dan Wasty Soeman. Kepemimpinan \& Supervisi Pendidikan. Jakarta: PT Bina Aksara, 2000.

Sudrajat, Hari. Manajemen Peningkatan mutu Berbasis Sekolah. Bandung: Cipta Cekas Grafika, 2004.

Sugiyono. Metode Penelitian Pendidikan Pendekatan Kuantitatif, Kualitatif dan R\&D. Cet. VI; Jakarta: Alfabeta, 2016.

Sukadi. Metodologi Penelitian Kompetensi dan Prakteknya. Jakarta: PT Bumi Aksara, 2008.

Sulaiman. Paradigma dalam Penelitian Hukum. Kanun Jurnal Ilmu Hukum,Vol.20, No. 2, 2018.

Susila, Ihwan. Pendekatan Kualitatif Untuk Riset Pemasaran Dan Pengukuran Kinerja Bisnis. Benefit Jurnal Manajemen dan Bisnis, Vol:19, No: 1, 2015. 
Sutedjo, Muwardi, et. al. Kapita Selekta Pendidikan Agama Islam. Jakarta: Direktorat jendral Pembinaan Kelembagaan Agama Islam, 2000.

Syukri. Peranan Kepemimpinan Kepala Sekolah dalam Meningkatkan Kinerja Guru pada SMP Nurul Ihsan Kabupaten Tolitoli Sulawesi Tengah, Tesis. Makassar: Program Pascasarjana Universitas Islam Negeri Alauddin Makassar, 2012.

Terry, George R. dan Leslie W. Rue. Dasar-dasar Managemen, Priciple of Management (Dasar-dasar Manajemen) terj. G. A. Ticoalu. Jakarta: Bumi Aksara, 2000.

Toha, Miftah. Prilaku Organisasi: Konsep Dasar dan Aplikasi. Jakarta: Raja Grafindo Persada, 2003.

Tim Pengembangan MKDK. Administrasi Pendidikan. Semarang: IKIP Semarang Press, 2003.

Usman, Husaini. Manajemen Teori, Praktik, dan Riset Pendidikan. Jakarta: Bumi Aksara, 2006.

Wahjosumidjo. Kepemimpinan Kepala Sekolah (Tinjauan Teoritik dan Permasalahannya). Jakarta: Rajawaali Pers, 2008.

Wahjosumidjo. Kepemimpinan Kepala Sekolah (Tinjauan Teoretik dan Permasalahannya). Jakarta: PT. RajaGrafindo Persada, 2013. 
The Leadership Management of School Principals in Improving Spiritual...

Wahyudi. Kepemimpinan Kepala Sekolah dalam Organisasi Pembelajar. Bandung: Alfabeta, 2009.

Wahyudi, A.S. Manajemen Strategi. Jakarta: Binarupa Aksara, 2001.

Wursanto, I.G. Dasar-Dasar Manajemen Umum. Jakarta: Pustaka Dian, 2000. 